\title{
Estimation of River Utroya Ecological State in Intensive Organic Pollution Area Using Plankton Communities' Characteristics (Pskov Region)
}

\author{
Diana Sudnitsina ${ }^{1}$, Anna Cherevichko ${ }^{2}$ \\ 1 - Pskov State University, Pskov, Russia,e-mail: pskov.pgpu.bot@mail.ru \\ 2 - Pskov department of FSBSO "State Research Institute of Lake and River Fish \\ Management”, Pskov, Russia, e-mail: pskovniorkh01@list.ru
}

\begin{abstract}
The changes in characteristics of phytoplankton and zooplankton communities in the river Utroya stretch with the active organic pollution were discussed. The paper shows the effects of pollution on the structural indicators of the communities (species composition, abundance, and biomass). Saprobical analysis was held. Assessment of ecological state of the river stretch was made.
\end{abstract}

Keywords - community structure, organic pollution, phytoplankton communities, saprobity, zooplankton communities.

\section{INTRODUCTION}

River Utroya (Ritupe) is a tributary of the river Velikaya that falls to the Pskovskoye-Chudskoye Lake. As the majority of small rivers in Pskov region, it is a typical plain river with low banks and sharply meandering channel. River has mixed feeding with prevalence of snow-fed. According to chemical composition water in riv. Utroya can be characterized as subsaline and slightly hard, according to ions composition water belongs to hydrocarbonate class [6].

As other small rivers of Pskov region, riv. Utroya is used not only for water intake but also for discharge of wastewater. Such kind of pollution is called active [2]. The main reason of riv. Utroya pollution on the territory of Pskov region is wastewater of rare settlements. Anthropogenic impact influences on biodiversity of water communities, decreases resistance of water ecosystems and self-purification capacity [7].

\section{MATERIALS AND METHODS}

In 2012 ecological state of riv. Utroya in intensive pollution area was estimated using bioindication method. Phytoplankton and zooplankton communities were used as bioindicators. Samples were collected at 3 stations situated in $100 \mathrm{~m}$ from each other: station №2 - area of waste and natural waters mixing, station №1 - upper stream area (nominally reference conditions), station №3 - downstream area. Sampling and evaluation of materials were made by standard methods [4].

\section{RESULTS AND DISCUSSION}

In phytoplankton of riv. Utroya researched area 44 algae taxons from 6 divisions have been found: Cyanoprokaryota - 6 (13.6\%), Euglenophyta - 4 (9.1\%), Chrysophyta - 1 (2.3\%), Bacillariophyta -21 (47.8\%), Dinophyta - 2 (4.5\%), Chlorophyta - 10 (22.7\%). Bacillariophyta dominates in species amount that is typical for river plankton [5]. The most diverse in this group are genera Navicula and Nitzschia.

Green algae, mostly nitrophilous Protococcophyceae (Scenedesmus, Pediastrum), were especially abundant at station №3 in May.

Blue-green algae represented mainly by filamentous forms (Phormidium, Lyngbia) were abundant at station closed to source of organic pollution (station №2) in summer. Its biomass reached 59.2\% from total phytoplankton biomass.

Quantitative phytoplankton characteristics (species amount, abundance and biomass) varied at different stations and seasons (Table 1).

The maximum species amount was found at station with reference conditions, minimum - at station №2.

According to biomass values water at reference station corresponds to oligotrophic zone, but trophicity level increases after discharge of waste water (station №2 and №3). The highest abundance and biomass values are registered at stations 1 and 3 in spring, at station 2 - in summer. Biomass decreases at all stations in September.

In phytoplankton 23 species are saprobionts (indicators of organic pollution of the water). Among them indicators of clear waters (o-saprobionts) count 1 species, indicators of mixed conditions (o- $\beta, \beta-0-$ saprobionts) -5 species. $\beta$-saprobionts $(77.3 \%)$, which prefer moderately polluted waters, dominate. Indicators of high water pollution $(\alpha-\beta, \alpha)$ presence at all stations. Their total amount counts $9.2 \%$. 
Sudnitsina D., Cherevichko A. ESTIMATION OF RIVER UTROYA ECOLOGICAL STATE IN INTENSIVE ORGANIC POLLUTION AREA USING PLANKTON COMMUNITIES' CHARACTERISTICS (PSKOV REGION)

TABLE I

STRUCTURAL CHARACTERISTICS OF RIV. UTROYA PHYTOPLANKTON AT DIFFERENT STATIONS AND SEASONS 2012

\begin{tabular}{|c|c|c|c|}
\hline Characteristics & Station 1 & Station 2 & Station 3 \\
\hline \multicolumn{4}{|c|}{ Spring } \\
\hline Species amount & 15 & 8 & 20 \\
\hline Total abundance, thousand cells/l & 620 & 300 & 1080 \\
\hline Total biomass, $\mathrm{g} / \mathrm{m}^{3}$ & 0.65 & 0.34 & 1.79 \\
\hline \multicolumn{4}{|c|}{ Summer } \\
\hline Species amount & 14 & 12 & 10 \\
\hline Total abundance, thousand cells/l & 500 & 520 & 440 \\
\hline Total biomass, $\mathrm{g} / \mathrm{m}^{3}$ & 0.56 & 0.98 & 0.54 \\
\hline \multicolumn{4}{|c|}{ Autumn } \\
\hline Species amount & 6 & 7 & 4 \\
\hline Total abundance, thousand cells/l & 90 & 130 & 250 \\
\hline Total biomass, $\mathrm{g} / \mathrm{m}^{3}$ & 0.14 & 0.17 & 0.10 \\
\hline
\end{tabular}

Saprobity indexes slightly changed on stations in different seasons and varied from 1.95 till 2.26, that corresponds to $\beta$-mesosaprobic zone, III water quality class $[8]$.

In zooplankton of riv. Utroya waste water discharge area following 20 species were found: rotifers (Rotatoria) represented by 2 species, copepods (Copepoda $)-5$, cladoceran (Cladocera $)-13$ species. During vegetation period zooplankton quantity varied in range $0.40-5.20$ thousand organizms $/ \mathrm{m}^{3}$ and 0.004 - $0.072 \mathrm{~g} / \mathrm{m}^{3}$ (Table 2). Maximum abundance and biomass at all researched stations registered in autumn, moreover in zooplankton community filterers (Bosmina coregoni, Ceriodaphnia qudrangula, Chydorus sphaericus) dominated.

Shannon-Weaver index calculated according to zooplankton biomass varied from 1.5 till 2.8 bits $/ g$. Low biodiversity was observed in spring during river flood.

Among zooplankton saprobionts $\beta$-o and $\beta$ saprobionts (indicators of slightly and moderately polluted waters) dominate $(65 \%$ from all species amount). Saprobity indexes for zooplankton ranged from 1.51 till 1.98 and corresponded to moderately organic polluted waters ( $\beta$-mesosaprobic zone) Maximum saprobity indexes were registered at station 3.
TABLE 2

ZOOPLANKTON ABUNDANCE (N: THOUSAND ORGANIZMS/M3) AND BIOMASS (B; G/M3) IN DIFFERENT SEASONS

\begin{tabular}{|l|c|c|c|c|c|c|}
\hline \multirow{2}{*}{ Stations } & \multicolumn{2}{|c|}{ Spring } & \multicolumn{2}{c|}{ Summer } & \multicolumn{2}{c|}{ Autumn } \\
\cline { 2 - 7 } & $\mathbf{N}$ & $\mathbf{B}$ & $\mathbf{N}$ & $\mathbf{B}$ & $\mathbf{N}$ & $\mathbf{B}$ \\
\hline $\mathbf{1}$ & 0.50 & 0.004 & 1.26 & 0.025 & 2.28 & 0.057 \\
\hline $\mathbf{2}$ & 0.40 & 0.014 & 1.30 & 0.022 & 4.65 & 0.072 \\
\hline $\mathbf{3}$ & 0.44 & 0.015 & 0.68 & 0.020 & 5.20 & 0.060 \\
\hline
\end{tabular}

\section{CONCLUSIONS}

It should be noted that structural characteristics of plankton communities and saprobity indexes at reference station weren't much different from the same characteristics at stations influenced by active pollution. It allows to assume the existence of organic pollution sources situated upper stream from researched area. This hypothesis is confirmed by some hydrochemical water characteristics, using for estimation of water objects ecological state (Table 3)

TABLE 3

SOME HYDROCHEMICAL CHARACTERISTICS OF THE RIVER UTROYA (GOSNIORKH DATA FUND, 2012)

\begin{tabular}{|c|c|c|c|c|}
\hline \multirow[t]{2}{*}{ Characteristics } & \multicolumn{2}{|c|}{ Station №1 } & \multicolumn{2}{|c|}{ Station № 3} \\
\hline & May & July & May & July \\
\hline Suspended matter, $\mathrm{mg} / \mathrm{l}$ & 6.3 & 2.9 & 3.9 & 2.5 \\
\hline Water colour, $\mathrm{Pt}-\mathrm{Co}^{\circ}$, grad. & 78 & 80 & 40 & 40 \\
\hline pH & 7.92 & 7.92 & 8.05 & 8.04 \\
\hline Permanganate oxygen consumed, mg O/1 & 22.7 & 8.0 & 21.2 & 7.2 \\
\hline Biochemical oxygen demand -5 day test , $\mathrm{mg} / \mathrm{l}$ & 1.47 & 2.27 & 1.44 & 0.99 \\
\hline
\end{tabular}


According to concept of ecological modifications [1] plankton communities' characteristics define the state of river Utroya researched area as the anthropogenic ecological stress with elements of ecological regress.

\section{REFERENCES}

[1] Abakumov V.A. Trends of the aqueous biocenoses' changes under environment pollution conditions. Problems of ecological monitoring and modeling of ecosystems. Leningrad, 1979. Vol. 2, pp. 37-48. [In Russian]

[2] Andrushajtis G.P., Melberga A.G., Rodionov V.I., Cimdin P.A. Implementation of rapid methods in surface water monitoring. Problems of baseline monitoring of environment conditions. Leningrad, 1984. Vol. 2, pp. 103-106. [In Russian]

[3] Barinova S.S., Medvedeva L.A., Anisimova O.V. Biodiversity of algae-indicators of environment. Tel-Aviv, 2006, 498 pp. [In Russian]
[4] Guidelines in methods of hydrobiological analysis of surface waters and bottom sediments / V.A. Abakumov et all. St. Petersburg, 1992, 220 pp. [In Russian]

[5] Okhapkin A.G. The history and main problems of river phytopancton researches. Botanical journal. 2000. Vol. 85. №10. pp. 1-10. [In Russian]

[6] Pskov region nature. Pskov, 1974, 172 pp. [In Russian]

[7] Trifonova I.S. Bioindication in limnological monitoring. Bioindication in fresh water ecosystems monitoring. St. Petersburg, 2007, pp. 23-28. [In Russian]

[8] Vykhristyuk L.A., Zinchenko T.D., Shitikov V.K. Integral assessment of plain rivers ecological state under anthropogenic impact. Scientific aspects of Russian ecological problems. St. Petersburg, 2001, 70 pp. [In Russian] 